\title{
Save journalism - to what end?
}

\author{
Tobie Wiese
}

I was given a rather sexy heading - 'Forget the rhino, save journalism' - under which to say a few words. I would agree with the assumption that both are under threat, but while most people will have a natural inclination to save an endangered animal I'm not so sure about how many will stand up for the survival of journalism. After all, why do we need journalism? And secondly, it seems to me that much of the woes that journalism is going through at present are self-inflicted.

It is often said, also in these turbulent economic times, that when America sneezes, the world gets a cough. It would therefore not be inappropriate to look at some of the cures that have been offered for the condition of journalism in the United States, because many of the trends that first manifested there have already made themselves felt here. To this end I will rely largely on, and refer to, work of the Committee of Concerned Journalists (CCJ), as it has been recorded by Bill Kovach and Tom Rosenstiel, in The Elements of Journalism.

Briefly, some background to their work: In June 1997 some 25 prominent newspaper editors, broadcasters, journalism educators and a few authors met at Columbia University to discuss the state of journalism in the United States. The reason for this was their conviction that there was something seriously wrong with the profession. They were worried about the state of journalism and the public distrust of the media. Also, they began to agree with the public that journalism was increasingly damaging public interest instead of serving it. They decided to engage both journalists and the public to determine what journalists were supposed to be and what the core principles of journalism were. The group formed the CCJ and over a period of two years held 21 public forums in which more than 3000 people took part, interviewing and gathering evidence from a few hundred journalists about their values. The now global project is ongoing and its progress can be viewed at: www.concernedjournalists.org.

The project results revealed nine core elements (principles, if you like) of journalism.

According to Kovach \& Rosenstiel the first element of journalism is:

\section{Journalism's first obligation is to the truth}

In their research Kovach \& Rosenstiel found that journalists were unanimous about their obligation to tell the truth. But what is truth?

Let's just look at one incident to illustrate a point here. A few days after he became president of the United States, Lyndon Johnson ordered the secretary of defence, Robert McNamara, to report to him on what was really going on with the war in Vietnam. Johnson didn't trust what he had been told as vice president. McNamara flew to Saigon, interviewed all the American generals and visited the various battle zones. On his return he gave a press conference in Washington where he stated 
that he was greatly encouraged by what he saw. The American forces were making good progress; the Viet Cong casualties were growing. In short, America was winning the war.

After the press conference McNamara went straight to the White House and reported to the president - which only became known years later - that the US plans in Vietnam were going awry. The Viet Cong reinforcements were outnumbering their casualties; the US forces had difficulty in making inroads and more troops were needed. In short, it was quite the opposite of what he was telling the American public a few hours earlier. That contradiction only came to light when the socalled Pentagon Papers were published eight years later. The point is that the press reported accurately and truthfully on what McNamara stated in public, but the reporting didn't get to the truth of what McNamara knew.

This is not the forum to debate truth in a philosophical sense - and we don't have the luxury that philosophers possess to declare that there is no such thing as truth. Our concern here is journalistic truth: while we are incapable of objectivity, we can and should pursue accuracy and fairness because that is what the public requires of us. But journalistic truth - Kovach \& Rosenstiel claim is more than mere accuracy. It is a sorting-out process that develops between the reporting of the, let's say, newsworthy event and the interaction amongst the public, the newsmakers and the journalist over time. Journalism by nature is reactive and practical and therefore the truth that the journalist is seeking must be truth in a sense by which we can operate from day to day. Getting the facts straight is not negotiable but more than that is required: journalism has to make sense of the facts; it cannot just relay the facts but should also convey the meaning of those facts.

Also, one should see journalistic truth as a process - or continuing journey toward understanding and meaning. Let's look at a real-life incident - or rather series of incidents - to illustrate the point. In the late 1990s a Hispanic immigrant in America by the name of Abner Louima was arrested for disorderly behaviour outside a nightclub in New York. It didn't make the headlines but a few days later a columnist for the New York Daily News found Louima in hospital and interviewed him. Louima revealed that police brutalized and sodomized him with a toilet plunger handle. The police immediately removed two officers who were involved in the arrest from active duty. Two days later in another interview Louima claimed that the arresting officers told him, 'This is Giuliani time. It's not Dinkins time' (Rudolph Giuliani was the New York mayor at the time and succeeded David Dinkins, an African-American).

More officers were pulled off duty and soon citizens staged protests in Brooklyn. The New York Times published an in-depth report suggesting that the drop in crime in New York coincided with wide increases in police harassment and brutality. A year later Louima recalled his allegation about the Giuliani remark but didn't mention the alleged assault on him. Several months later the Manhattan Institute's City Journal published an article making the point that despite high profile incidents of police brutality the New York Police Department had a relatively good record on the issue of police brutality.

With this in mind Kovach \& Rosenstiel argue that the truth here is a complicated and sometimes contradictory phenomenon, but seen as a process over time, journalists can get at it. They did so here by stripping information that came to their knowledge of any attached misinformation, disinformation or self-promoting information and allowing the community and public institutions to react. In this way, the search for truth becomes a conversation.

The second element is: 


\section{Journalism's first loyalty is to the citizens}

In a survey done by the CCJ more than 80 percent of the journalists, when asked who they worked for, replied that they were working on behalf of their readers, viewers or listeners. This rather is reassuring but there are clear trends that this basic belief is being undermined.

People who gather news are not like employees of other companies. They have a social obligation which can actually override their employer's immediate interests at times, and yet this obligation is the source of their employer's financial success. This allegiance to the public is the meaning of what has become known as journalistic independence.

The code of ethics of the American Society of Newspaper Editors puts the principle of independence above all and states: 'Freedom from all obligations except that of fidelity to the public interest is vital. Promotion of any private interest contrary to the general welfare, for whatever reasons, is not compatible with honest journalism'.

Kovach \& Rosenstiel point out how the business concept of Management by Objective has, over the last fifty years, been adopted by many news organisations. It is now a common occurrence both in the US and in South Africa that the salaries and/or bonuses of top news executives are directly tied to their publications' financial performance. One may ask, what is wrong with that? What good is journalism if it doesn't sell?

The problem is that by tying a journalist's income to his organisation's financial performance in effect changes the journalist's allegiance. The company is explicitly saying that a good portion of your loyalty must be to the corporate parent and to shareholders - ahead of readers, viewers or listeners.

\section{The essence of journalism is a discipline of verification}

The discipline of verification - the checking of facts with more than one source, the seeking of multiple witnesses to an event, the disclosure of as much as possible about sources, the obtaining of various views on a matter - all of that is what separates journalism from entertainment, propaganda, fiction or art. Entertainment focuses on what is most diverting. Propaganda will select facts or invent them to serve the purposes of persuasion and manipulation. Fiction invents scenarios to get at a more personal impression of what it calls truth. Only journalism is focused on getting what happened being recorded accurately. As Walter Lippmann put it almost 90 years ago, 'There can be no liberty for a community which lacks the information by which to detect lies.'

What could the public expect from the media as part of the discipline of reporting?

- Never add anything which was not there;

- Never deceive the audience ;

- Be as transparent as possible about your methods and motives;

- Rely on your own original reporting;

- Exercise humility.

The fourth element:

\section{Journalists must maintain an independence from those they cover}


This refers to independence of spirit and mind - and does not mean neutrality.

If applied to the political arena, what comes to mind is the position and reporting of Journalist A from Newspaper A which supports Political Party A. All of them are exercising their democratic and legal rights.

Now consider the position of that journalist when she or he has to report on the affairs of Political Party B, a direct political opponent. The journalist cannot be neutral. But what we may expect of him or her is dedication to accuracy, verification, the larger public interest and a desire to inform.

\section{Journalists must serve as an independent monitor of power}

It is interesting to note that as long ago as 1644 a publication in England called The Spie promised readers that it planned on 'discovering the usual cheats in the great game of the Kingdome. For that we would have to go undercover'. Clearly, for centuries now, people in power have been prone to abusing their power, and - clearly - their subjects are convinced that somehow, by making this public, a process will be triggered which will ultimately lead to a rectification of the situation.

This role of being a watchdog is well-known and well-defined and I don't think I have to elaborate much on this, apart from drawing attention to Kovach \& Rosenstiel's observation that much of what is being offered nowadays on US television as investigative reporting is not much more than entertainment. A case in point is a TV series which exposed how a certain bra's metal wires could poke the owner, or another one on the dangers of opening and closing doors. These kinds of programmes do not monitor the powerful elite or guard against the potential for abusive power. In 1997 about only 1 in 10 of these programmes concerned the combined topics of education, economics, foreign affairs, the military, national security, politics or social welfare - or any of the areas where most public money is spent.

\section{Journalism must provide a forum for public criticism and comment}

Suffice to say that this duty of the press must be built on the same principles as the rest of journalism - namely that of truthfulness, facts, fairness and verification. A forum without regard for facts fails to inform. A debate steeped in prejudice and supposition only inflames. Also, a useful forum must be for all sections of the community, not just the affluent or demographically attractive.

\section{Journalists should make the significant interesting and relevant}

Kovach \& Rosenstiel argue that the dialectical way in which we tend to talk about the news interesting versus relevant, fun and fascinating versus important, information versus storytelling, what people want versus what people need - is not helpful. That is so because this is not how journalism should be practiced and this is not how people come to the news. The evidence suggests that most people want both - they read the sports and the business pages, the in-depth reports and the cartoons, the book reviews and the crossword puzzles.

Most journalism, like most communication, exists in the area between storytelling and information. The journalist's task is to find a way to make the significant interesting and relevant for each story because journalism is storytelling with a purpose. That purpose is to provide people with the information they need to understand the world. The first challenge is to find the information that people need to live their lives. The second is to make it meaningful, relevant and engaging.

\section{Journalists should keep the news in proportion and make it comprehensive}


An analogy with cartography is quite useful as journalism can be seen as modern-day cartography: it creates a map for citizens to navigate society. That is its utility and its economic reason for being.

The analogy also helps to clarify the question of what journalism has a responsibility to cover. As with any map, journalism's value depends on its completeness and its proportionality. When we devote far more time and space to a sensational trial or celebrity scandal than we know it deserves because we assume it will sell - we act like the ancient cartographers who would give impressive prominence to their own countries and areas and left little space for the rest of the world. It may make short term economic sense but it misleads the traveler and eventually destroys the credibility of the mapmaker. Thinking of journalism as map-making helps us to see that proportion and comprehensiveness are key to accuracy.

Finally:

\section{Journalists have an obligation to personal conscience}

Briefly, this concerns the point that a journalist should never be in a position where she or he is forced, even implicitly, to do or write anything that is contrary to their conscience.

Having dealt with these nine salient points I will now share a few comments that I gathered from magazine editors at Media24 in response to the question what junior journalists could expect when joining the media industry:

Suzy Brokensha, editor of Fairlady magazine:

- Print may be on the decline (this is debatable, of course) but content is not: there will always be a need for excellent content, so make the gathering of that content, and the elegant presentation of it, your mission;

- If writing is your profound passion and you really feel you have something to say to the world, you should probably become a novelist rather than a journalist. Working for a magazine or a newspaper will always mean writing within certain parameters, and you may not always agree with all of them. It's the voice of the publication that is important, not your own. Even columnists, who are allowed more freedom and more of an individual voice than most other writers, are not free to write exactly what they choose. You have to be prepared to accept that;

- Because of the relatively mediocre salaries, there is a high staff turnover in many magazines and newspapers. But you'll need to be prepared to come in at a low level and to work there for as long as it takes before you move up in the business: media is still one of those businesses where you need to pay your dues, and where experience really shows. You will have to learn to ignore the siren calls of PR (much better money, but not as much fun in the long run).

Melinda Shaw, editor of heat magazine:

- Working for a weekly magazine such as heat requires a very specific skill set that is a combination of out-the-box thinking, tenacity, the ability to get people on your side so that they want to talk to you, and to write as you would talk to your friends... All this, and speed! When I interview reporters I look for someone with a can-do attitude who is honestly interested in entertainment and celebrity news - passion is very easy to spot, and the best reporters who have worked for heat were those who were really passionate about what they 
did for a living. Very few people come to heat knowing everything about celebrities,

- but the good ones are invariably a bit obsessed about a TV show, a website, a blog or a band, and have a strong opinion about at least one celebrity;

- A weekly deadline comes with a lot of pressure: you have to think fast, and if one avenue doesn't work out, be able to change direction and quickly find another source who'll give you what you need. So networking and making contacts is hugely important, so you can call in favours when the heat is on! And I always tell heat reporters to see the magazine as the cool friend who has the lowdown on everything - which is why she's so popular;

- The writing style is very specific too: you write a story the way you would tell your friends about it at a braai or over drinks, not in a formal, linear newspaper kind of way, but assuming some shared knowledge, alluding to shared opinion of the subject at hand, and with a novel take on the story that everyone is talking about. And even when you are getting a dig in, you have to work to prevent it sounding bitchy - that's the lazy way out and will not be tolerated - but the funnier you can be about it, the harsher you can be. It's hard to sound effortless, but that is the trick when writing for heat - there is absolutely no effort required from the reader because we craft every word, every sentence, every caption to have maximum impact.

Siobhan Cassidy, group managing editor of Media24 Africa:

- It is the questions you ask, rather than the answers you give that matter most. A fistful of degrees won't get you far if you don't have a strong sense of curiosity, an open heart and a thick skin.

Kevin Jacobs, managing editor of $Y O U$ magazine:

- Journalism as an occupation is hard to capture in a succinct one-line description. It's a job, a salary earner. It can be a career. It can be a vaguely amusing way-station en route to other professional paths. Or a practice field for budding PR types or marketing executives. But at its most frustrating and most glorious it's an infectious disease for which, happily, there is no cure;

- If you wish to earn like a hedge fund honcho become a stockbroker. Do not become a journalist; you will not become wealthy from journalism. But you will be enriched, intellectually and emotionally. You will at times feel terrified, exasperated, angry, overawed, determined, despondent . . . and triumphant;

- Do not go into journalism if you believe the world owes you a Ferrari lifestyle - or in fact owes you anything. But do take up the pen if you want to let light into dark places or contribute to the fall of fatuous politicians or the triumph of the humble and good. It's enriching if at the end of your working life you can say for instance, 'I have attended the installation of a new king, shaken hands with a reigning king and attended the funeral of a former king. I have reported from a local town hall, the Security Council of the United Nations, diplomatic gatherings in Geneva, grass-hutted villages in Africa, the steppes of Central Asia, the wild grassland of South America, and from opposing sides in warfare';

- Hey, if this sounds pretentious ask yourself, how many stockbrokers get to say it?

Finally, Fairlady editor Suzy Brokensha again:

- If you can write humour successfully, you will always be fine. It's the most difficult thing to do well, and there is always a huge demand for funny writers;

- Do not be precious about your work: a writer is never the best editor of their own work; 
- Online experience is highly sought after - the ability, at this stage, to fashion the same content for both print and online is invaluable - and not as easy as it sounds;

- Don't complain about doing something that is out of your particular sphere: if you're a writer, be prepared to proof-read, too; if you're a copy editor, be prepared to write the odd advertorial or do the odd review: all of it adds to your experience in the long run and will not only improve your abilities but will also improve your employability. Basic motto? Pitch up, and pitch in. This is a highly competitive industry - learn how to make yourself invaluable;

- Media is the best business in the world - if you manage to remember that it is a business. We live in one of the most exciting countries in the world, and you're about to go into one of the most exciting industries in this country. And I can't imagine why you would want to do anything else.

\section{References}

Committee of Concerned Journalists. www.concernedjournalists.org; Accessed: 2008-10-10.

Hargreaves, I. 2003. Journalism. Truth or Dare? New York: Oxford University Press.

Kovach, B. \& Rosenstiel, T. 2001. The Elements of Journalism. New York: Three Rivers Press.

\section{About the speaker}

Tobie Wiese is the Manager of Media24 Learnerships (Magazines) in Cape Town. 